\title{
Impact of Sustainability on Design and Construction of Civil Engineering Infrastructure
}

\author{
Oyedele $\mathrm{OA}^{*}$ \\ Building Technology, International Project Management, UK \\ *Corresponding author: Oyedele OA, Building Technology, International Project Management, UK
}

\begin{abstract}
Buildings and their construction together account for 36 percent of global energy use and 39 percent of energy-related carbon dioxide emissions annually. Globally, the embodied carbon of buildings account for about 11 percent of emissions. The design and construction of civil engineering infrastructures are impacting global warming and climate change and the world is facing a big challenge in the form of environmental degradation occasioned mainly by global warming due to ozone layer depletion, fauna loss, deforestation and pollution. A new UN Environment Programme (UNEP) report cautioned that unless global greenhouse gas emissions fall by 7.6 per cent yearly between 2020 and 2030, the world will miss the opportunity to get on track towards the 1.50 temperature goal of the Paris Agreement on the eve of a year that nations are due to strengthen their Paris climate pledges. Civil Engineering designers and contractors are now concerned more than before about the implications of climatic changes taking place globally due to environmental mismanagement in the form of desertification, pollution, construction on inappropriate sites, non-renewable energy consumption, high-density habitation, improper waste management, bush-burning, over-usage of cement, steel and concrete etc. They have resolved to embark on sustainable design and specify sustainable materials for construction. Sustainable construction is now the vogue with sustainable infrastructures having an edge over unsustainable ones in the real estate market. Sustainability is impacting the design and construction of civil engineering infrastructure and that is the discussion in this paper.
\end{abstract}

Keywords: Civil engineering infrastructure; Deforestation; Green building; Sustainability; Sustainable development

\section{Introduction}

Sustainability is the avoidance of the depletion of natural resources so as to preserve an ecological balance in an environment. The principles of sustainability are the foundations of what the concept of sustainability represents. Sustainability is made up of three pillars: economic, social and environment. These principles are also informally used as profit, people and planet. In the United States, the Environmental Protection Agency (EPA) defines sustainable construction as "the practice of creating structures and using processes that are environmentally responsible and resource-efficient throughout a building's life-cycle from siting to design, construction, operation, maintenance renovation and reconstruction" [1]. Environmental mismanagement resulting in degradation, decay and demise of lower level living things in the ecosystem is a great challenge of the global community in recent times [2]. This degradation has brought about the imminent global warming due to ozone layer depletion, loss of fauna and biodiversity due to deforestation and pollution. Of greater concern than other issues are the problem of desertification because of its effects on the environment like climate changes and global warming and its negative impact on civil engineering infrastructures. Mainly, desertification is a product of forest clearing for agriculture, construction projects and bush-burning. The effects of this environmental mismanagement are the cause of various meeting of nations across the world [3].

The Intergovernmental Panel on Climate Change (IPCC) was set up by the World Meterological Organisation (WMO) and the United Nations Environment Programme to provide an objective source of scientific information. In 2013, the IPCC made available more clarity about the role of human activities in climate change when it released its Fifth Assessment Report. It is categorical in 
its conclusion; climate change is real and human activities are the main cause [4]. The government of London commenced Congestion Charging to lessen pollution in the city of London. But basic science explains that in photosynthesis, carbon dioxide is an input of plants production of energy [5]. A simple project to neutralize the effects of environmental carbon pollution will therefore be the afforestation of our urban areas. This simple principle must have informed the decision of the Lagos State Government of "one man one tree". With this scheme and with a population of over 9 million according to National Population Commission (NPC) census of 2006, Lagos State is poised to plant over 9,000,000 trees in recent times. Trees and of course, afforestation can act as shield or buffer to the Lagos slums. It can also serve as windbreaker, thereby preventing storms and floods. In developed countries, plants are used to differentiate communities and create sense of belonging among inhabitants. One of the most devastating disasters in America was Hurricane Katrina. It took place as from August 29, 2005, in east New Orleans [6]. This activity was credited to the effect of global warming by experts in environmental science. Hurricane Katrina made all the civil engineering infrastructures in east New Orleans ineffectual. "In the aftermath of the widespread devastation caused by Hurricane Katrina, the Federal Emergency Management Agency (FEMA) deployed a Mitigation Assessment Team (MAT) to evaluate building performance during the event, and the adequacy of building codes and construction practices in place at the time" [7]. Hurricane Katrina has changed the way construction is done in New Orleans. This paper evaluates the various ways that sustainability is impacting the design and construction of civil engineering infrastructure.

\section{Review of Literature}

Foster [8] stated that "Architecture is an expression of values - the way we build is a reflection of the way we live. This is why vernacular traditions and historical layers of a city are so fascinating, as every era produces its own vocabulary". Architecture has to shift, evolve and develop in parallel to its society, the lifestyle, economy and the technology available [9]. This is why glass, steel and concrete were the domineering building materials after the World War II. Before the World War II, it was the Gothic, Victorian, Neoclassical, Art Deco, Baroque, Art Nouveau, Bauhaus, Deconstructivism, Beaux Arts and Modernism architecture. Now, it is sustainable architecture Civil engineering infrastructures are transportation facilities like roads, railways and bridges, power lines, buildings, dams, stadiums, hospitals etc. They are the physical infrastructures that support life. According to Okeola Salami [10], the governments of developed nations have become more intensely interested about cascading infrastructure failures and are developing strategies for controlling and mitigating them. According to Horgan [11], work on Canrobert Street in Bethnal Green used approximately 100 recycled tyres mixed into a new road surface laid by council contractors, J. B. Riney.
Green building is the practice of creating structures and using processes that are environmentally responsible and resource-efficient throughout a building's life cycle from siting to design, construction, operation, maintenance, renovation and deconstruction. This practice expands and complements the classical building design concerns of economy, utility, durability, and comfort. Green building is also known as sustainable or highperformance building [12]. According to Oyeyipo, Okoh, James [13], the 2012 flash floods look unwavering to disturb much more people than those who reside in flood plains. The floods that have displaced about two million residents in Kogi State, Nigeria, have affected travelling to the Federal Capital Territory (FCT) by motorists transiting from the South. Floating building may be the solution to flooding in residential areas with boat as means of transport. A floating building is a building unit with a floatation system at its base, to allow it to float on water. It is common to define such a building as "permanently moored" and not usable in navigation. Floating building will float in period of flood and berth when there is no flood. These buildings can be chained in a location to eradicate movement.

Lagos harbor that is part of the Lagos lagoon is the lone aperture for nine of the coastal or marginal lagoons to the sea. There is no natural rocky shore in Nigeria; nevertheless, at the mouth of the Lagos harbour, there exists a rocky outcrop (stone moles) in the form of harbour breakwaters. These moles were mainly constructed (i.e. the east, west and training moles) between 1901 and 1930 to protect the Lagos harbour from siltation (natural sediment flow), thus allowing the easy passage of ocean-going vessels to berth in the Lagos harbour, ports, wharfs and other terminals inland [14]. Of late, climate variability and change have been threatening the stability of the Lagos harbor. Amazon region of Brazil, according to Mongabay [15], has lost more than 60,000 square miles (150,000 square kilometers) of rainforest since 2000. This area is bigger than the size of State of Georgia in the United States of America or Bangladesh country in Asia or more than forty times the size of Lagos State, Nigeria. This lost of forested land was as a result of widespread bush fires in the Amazon region following a steep drop in deforestation rates since 2004. Most of these havocs have been driven by clearing for cattle pasture and agriculture (planting of arable crops and poultry), often in conjunction with infrastructure development and improvements including construction of roads, residences, bridges and storages. Increasing commodity prices, especially for beef and soy, have further motivated forest destruction in the Amazon region [16]. The roles of green infrastructure - forest, savannah and parks in human settlements have been highlighted by scientists and researchers [17]. Wright [18] in National Parks and Protected Areas explored the roles that national parks play in preserving and understanding biodiversity and related ecosystem processes. According to Wright [18], "the gateway to the conservation effort, parks can no longer be 
viewed as distinct, separate entities. They must be understood and managed in the context of their surrounding ecological and cultural landscapes". Forested areas, parks and protected areas serves as the reasons why ecosystem management represents a functional model and serves as the supporting historical, political, ecological and legal bases for human communities.

Successfully, forests can be used to create sustainable regions and demarcate cities. This partition can create a distinct sense of belonging and healthy competition among cities. It reduces metropolis and makes management of transportation, electricity and water easier. Regional planners, for example have emphasized that human settlements should exist in a given ratio with plants. Williams [19] challenges professionals to rethink architecture and to view their projects not as objects but as critical, connected pieces of the whole, important to human health as well as to regional economy and ecology. According to Bergman [20], "The rationale for ecodesign reach far beyond the singular goal of mitigating climate change to include setting the stage for the future - the sustaining - of our species and aspiring still further to a positive outcome: improving the quality of our lives. Our building of the future should include the way we think and do things so that building is not demolished and reconstructed regularly. Austria showcase one of the most developed sustainable construction markets with around 76,000 residences and one-family houses being approved for construction in Austria in 2018. Vienna alone has 24,000 units. These buildings will be made of wood, natural interior materials and renewable energy [21]. According to Ramsey, Sleeper, Hedges [22], "Buildings and the built environment play a major role in the human impact on the natural environment and on the quality of life; sustainable design integrates consideration of resource and energy efficiency, healthy buildings and materials". Many people view the requirements of governments, local authorities, companies and clients to construct buildings and structures sustainably to be an optional extra, an additional burden on business, believing sustainable construction methods should only be adopted because of a need to comply with legislation or for financial reasons [23].

\section{How sustainability is impacting the design and construction of civil engineering infrastructure}

Around $40 \%$ of total energy consumption and greenhouse gas emissions are directly due to construction and operation of buildings. The best way to reduce this impact is the use of green buildings construction techniques. The cement industry is one of the two largest producers of carbon dioxide (CO2), releasing a potent greenhouse gas. According to Berardi [24], "The building sector is receiving increasing attention in worldwide policies for sustainable development". Buildings are now design with plants around them and incorporating renewable energy use. Sustainable architecture is architecture that seeks to minimize the negative environmental impact of buildings by efficiency and moderation in the use of materials, energy, and development space and the ecosystem at large. Sustainable buildings use renewable energy and architects are now designing buildings using solar panel as roof materials and roads lights using solar energy. Designers are incorporating natural lighting and ventilation to reduce energy consumption in their modern design. Occupancy motion sensor light detects when occupants are in a room and goes off as soon as there is no occupant. This system will reduce energy consumption in buildings. In rooms with good daylight conditions, the motion sensors should have built in light sensors [25]. Natural fibre (NF) of different parts of plants, such as fibres extracted from the stem, leaf, or seed are being tested as reinforcing material in cementitious concrete [26].

Architects are now introducing the use of modern construction materials which are sustainability compliant. They are experimenting with new materials and techniques that gave them greater freedom to create new forms. In 1903-1904 in Paris, Auguste Perret and Henri Sauvage began the use of reinforced concrete to build residential apartments/buildings which was previously only used for industrial buildings. The safety, stability and permanence of a building depend very largely upon the crust of the earth immediately beneath it [27]. According to Li [28], "Currently, no one can doubt the importance of low carbon living and low carbon architecture. Numerous new materials and high technologies have been used in the country all over the world in the course of low carbon architecture's development, some of which have had a favourable result, such as London zero carbon emissions pavilion at the 2010 Shangai World Expo". We all know that building material is the basis of the construction industry; it cost a lot of energy. For building material, walking a way of ecological building material is necessary to adapt to the continued economic growth and meet the need of sustainable development. Concrete is now being recycled and reused in the construction of buildings. Aluminum encasement filled with shredded waste materials is being used as walling materials for construction of manufactured buildings. Balfour Beatty, the contractors that handled the Birmingham New Hospital project, appointed Premier Waste to manage all wastes produced during construction of the hospital [29]. Balfour Beatty addressed waste reduction, recovery and management throughout the planning, design and construction stages of the project, by working with subcontractors, suppliers and waste management contractors to develop and apply a range of approaches and mechanisms. These waste management mechanism included: designing out waste; establishing benchmarks and targets for material wastage and recycling; setting contractual requirements on subcontractors and suppliers for waste production, handling and management; establishing take-back schemes with suppliers for specific material streams and using closed-loop recycling in the construction of 'green rooms'; using an on-site waste management contractor to coordinate the management of waste on site; and using off site 
waste management contractors to recover the segregated and mixed waste arising.

\section{Sustainable development of civil engineering infrastructure}

Sustainable development of our built environment involves the incorporation of plants in all civil engineering designs and construction. Designers and constructors of civil engineering infrastructures are now realizing the contributions of plants and modern construction materials, methods and practice in sustainable civil engineering infrastructure. Report of the World Commission on Environment and Development (WOED), otherwise known as Brundtland Report [30] in "Our Common Future" initiated the idea of sustainable development and stated that it is a "development which meets the needs of the present generation without compromising the ability of future generations to meet their own needs". This definition is laudable and considered that our environment is not owned by only the present generation. This definition is not adequate due to the fact that it undermines the ability of our future generations to solve their environmental challenges.

Can we determine the "developments that meet our needs in relation to future generations' ability to manage their environmental challenges"? Some decades past, it was thought that some wastes could not be recycled.Zero-carbon projects, catalytic conversion and pyrolysis have made it possible to recycle all wastes. "All definitions of sustainable development require that we see the world as a system-a system that connects space; and a system that connects time" [31]. Sustainable development approach emphasises that we live now in a borrowed environment from future generations. The design and construction of civil engineering structures should lay emphasis on sustainability.

There is a later definition which stated that sustainable development is a "development that ensures a better quality of life for everyone now and for generations to come". This is comprehensive and adequate. It dictates that we should not compromise our ability to develop our environment now because of the future generations' capacity to develop theirs; instead, we should think of the future generations' quality of life in all our economic, social or environmental developmental projects. "The latter definition is better than the former in that it takes into consideration the fact that anything we are doing now, we assume we are doing it permanently and not to be re-done by the coming generations" [32]. Sustainable civil engineering development should integrate the design of balancing the eco-system so that we do not alter the heritage bestowed on us by our ancestors and leave a befitting heritage to our inheritors. The natural features of our environment should hence be our goal in our various development projects.

\section{Conclusion}

Civil engineering structures though have great impact in carbon dioxide generation during and after construction, the designs and construction of these structures can be done to impact sustainability of the structures, reduce global warming and improve health of users. Green building which is popular in Guangzhou, China, is a method of aiding the sustainability of civil engineering structures. With green buildings, there is no necessity to paint the external walls of buildings. Architects and contractors now lay emphasis on the use of sustainable materials in the construction of structures. Civil engineering structures have a crucial role to play in the sustainable development of our environment in that it contributes about 40 percent of energy-related carbon dioxide emissions annually. Any measure that can reduce or totally stop this emission will impact climate change and global warming. This is why all governments are laying serious foundations for the enthronement of sustainable civil engineering design and construction. For example, trebleglazed windows and concrete-sandwiched doors will keep house warmer by reducing heat lose than single or double-glazed windows and flush doors. Re-use of stones from construction sites, will also reduce manufacture of new blocks for construction purposes. Plastic materials and aluminum are now didely used as building materials. Though concrete reused in construction as material for concrete gives lesser 'crush strength', adding more reinforcement and cement will give better strength. Wood can be carved to replace plaster of Paris (POP) in ceiling decoration and wall papers give finer and colorful designs on internal walls than POP.

\section{References}

1. US EPA (2018) Basic Information. Green Building, USA.

2. Oyedele $O$ (2010) Global warming: Is it as bad as it's made out to be?

3. Philander SG (2012) Encyclopedia of Global Warming and Climate Change. sage $3(2)$.

4. United Nations (2019) Climate Change. USA.

5. Bazzaz FA, Fajer ED (1992) Plant Life in a $\mathrm{CO}_{2}$-Rich World. Scientific American 266(1): 68-77.

6. New York Times (2005) Huricane Katrina slams into Gulf coast, Dozens are dead. USA.

7. Ingargiola J (2015) Did Katrina change the way we build? A Building Science Perspective. News and Views 28(4).

8. Foster N (2014) Norman: Biography, Quotes and Philosophy. UK.

9. Fiorentino J (2016) Built in stones. Times of Malta.

10. Okeola OG, Salami W (2011) Nigerial's Rngineering Infrastructure Dilemma: From Lamentation to Action. R Gate 2(1): 55-61.

11. Horgan R (2020) London's first recycled 'rubber road' is laid. New Civil Engineer. UK.

12. US EPA (2020) Green Building: Basic information. USA.

13. Oyeyipo S, Okoh G, James S (2012) Flood Havoc: Travellers Still Stranded on Abuja-Lokoja Highway, as More Communities Get Submerged. This Day. 
14. Onyema I (2012) Tackling ocean surge at Kuramo Beach. The Punch.

15. Mongabay (2008) Amazon deforestation forecast for 2008 reviewed downward.

16. Andersen LE (1997) A Cost-Benefit Analysis of Deforestation in the Brazilian Amazon. Institute for Applied Economics Research (IPEA) in Rio de Janeiro.

17. Sayer JA (1998) Changing roles of forest research. In: Tropenbos. Seminar proceedings "Research in Tropical Rain Forests: Its Challenges for the Future" p: 59-63.

18. Wright RG (2010) National Parks and Protected Areas: Their Role in Environmental Protection. Blackwell Publishing, London.

19. Williams DE (2007) Sustainable Design: Ecology, Architecture, and Planning. Wiley Publishers, London.

20. Bergman D (2013) Sustainable Design: A critical Guide. Hudson, Princeton Architectural Press, USA.

21. Merzeder W (2019) Sustainable Construction in Austria. Austria.

22. Ramsey CG, Sleeper HR, Hedges KE (2011) Architectural Graphic Standards: Students Edition. Wiley Publishers, London.

23. Goodhew S (2016) Sustainable Construction Processes: A Resource Text. John Wiley and Sons. UK.
24. Berardi (2013) Moving to Sustainable Buildings: Paths to Adopt Green Innovations. Versita Publishing, London.

25. Energywise Consoprtium (2012) Practical Guide to Energy Management of Facilities and Utilities. Ohio: Smithers Rapra.

26. Ahmad R, Hamid R, Osman SA (2019) Physical and Chemical Modifications of Plants Fibres for Reinforcement in Cementitious Composites. J Advances in Engineering.

27. Ward-Harvey K (2009) Fundamental Building Materials. Irvine, Universal Publishers, California, USA.

28. Li L (2010) Advances in Building Materials. Trans Tech Publications Limited, Switzerland.

29. WRAP (2020) Waste management and recovery at Birmingham New Hospitals-Wrap.

30. Brundtland Report (1987) Our Common Future: Report of the World Commission on Environment and Development. Oxford University Press, United Nations.

31. Gagnier D (2010) What is Sustainable Development?

32. Oyedele 0 (2006) Tinubu and Integrated Waste Management. Vanguard Newspaper p: 33.

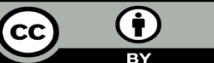

This work is licensed under Creative Commons Attribution 4.0 License

To Submit Your Article Click Here: Submit Article

DOI: 10.32474 /TCEIA.2020.03.000174

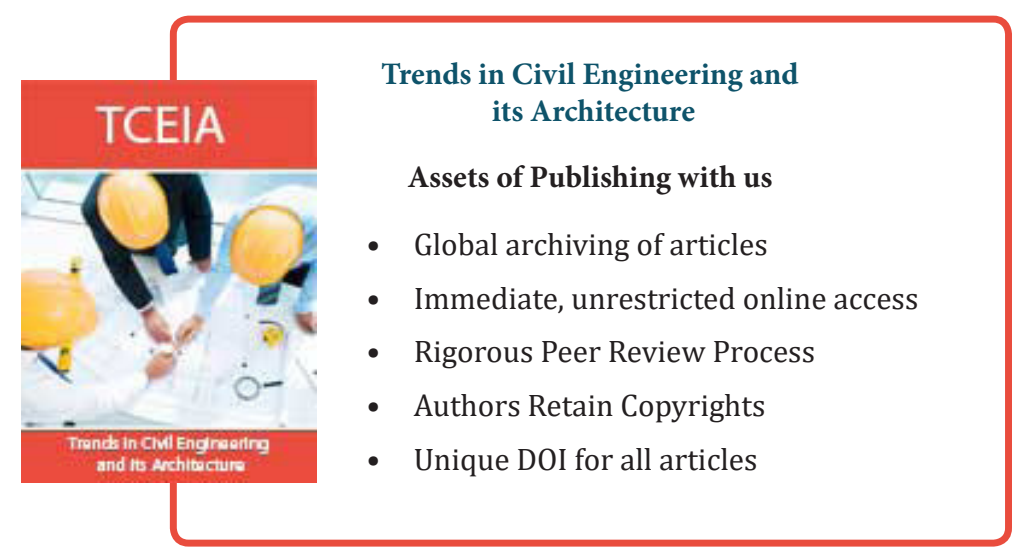

